\begin{tabular}{cr}
\hline Научни скуп & ISBN 978-86-6191-062-3 \\
Наука и настава у васпитно- & DАКУ \\
образовном контексту & ПДК 37.015:159.953 \\
Педагошки факултет у Ужицу & Прегледни научни чланак \\
23. октобар 2020. & стр. 335-346 \\
\hline
\end{tabular}

\author{
Mara Cotič $\check{c}^{*}$ \\ University of Primorska, Faculty of Education \\ Darjo Felda* \\ University of Primorska, Faculty of Education \\ Amalija Žakelj* \\ University of Primorska, Faculty of Education
}

\title{
TAXONOMY OF LEARNING OBJECTIVES AT ELEMENTARY LEVEL
}

\begin{abstract}
Looking for an answer to the question what knowledge represents the centre of gravity in teaching and learning and thus also in testing and assessing knowledge, as well as in the interpretation of students' achievements taxonomies of learning objectives for the cognitive area can be of assistance. In education sciences there are several taxonomies of cognitive knowledge (Bloom, Marzano, Gagne). Taxonomy is derived from basic cognitive - mental processes that are arranged in a hierarchic relationship, namely from the lowest - the simplest to the highest - the most complex process.

The present paper represents an introduction to Bloom's, Gagne's, and Marzano's taxonomies. Bloom's taxonomy is one of the best known classifications of learning objectives, where Bloom and associates have formed a taxonomy of cognitive, conative, and psycho-motoric learning objectives. In the cognitive area the following degrees have been defined: remembering, understanding, applying, analysing, synthesising, and evaluating. Gagne's classification of knowledge classifies the achievements of learners into: basic and conceptual knowledge, procedural knowledge, and problem solving knowledge. Marzano's taxonomy distinguishes between content and lifelong or process knowledge, which are further divided into complex thinking, data processing, communication, cooperation in the group, and development of mental habits.
\end{abstract}

Keywords: taxonomy, Marzano's taxonomy, Bloom's taxonomy, Gagne's classification of knowledge, knowledge testing.

${ }^{*}$ mara.cotic@pef.upr.si

*darjo.felda@pef.upr.si

*amalija.zakelj@pef.upr.si 
Cotič, M., Felda, D., Žakelj, A.: Taxonomy of Learning Objectives at Elementary...

Научни скуп „Наука и настава у васпитно-образовном контексту” • стр. 335-346

\section{INTRODUCTION}

The quantity of one's knowledge is not always directly proportionate to the knowledge that she or he transmits to others. Learners mainly need and value the latter. A majority of learners at the level of elementary school have very good opinion about their teacher; even more - they nurture a very special emotion toward their teacher that is an interlacing of respect and love. Teachers at the elementary level thus have great power and influence over the work of their pupils as for them teacher's words are usually "sacred". Taking account of this, teachers should dedicate more attention to their ways of teaching. From the very first day the child comes to school they could - via goal oriented activities with the assistance of playing - offer the child more opportunities to become familiar with mathematics and with other areas of knowledge with all the senses and with as active an approach as possible.

A Chinese wisdom says: what I hear I forgot; what I see I remember; what I do I learn. If we wish the knowledge of our pupils to last, we must get them used to independent work. It must begin at school and continue at home. The art of teaching mathematics lies not in transmitting ready-made results and recipes to learners, but in inspiring them for work with interest or/and with useful problems that will not leave them be in peace until they have found a solution. The tasks set must of course be appropriate for the learner's knowledge and abilities and the demand level must be increased slowly (Kmetič, 1996).

In today's school practice it happens all too often thatteachers, mainly due to lack of time, look for ways of teaching that will quickly lead to the set goal. Sometimes this path proves indeed to be shorter, especially when we avail ourselves of passive methods of teaching such as explanation, demonstration, talking, etc. Doing so we are, however, not aware that this passive reception of the learning matter leads to acquiring and managing knowledge only at the lowest taxonomy levels with which the learner cannot develop adequate mental processes and skills that lead to applicable knowledge.

Modern strategies of learning and teaching have brought great changes into the learning and teaching of mathematics and in consequence also into the testing and assessment thereof. Today the goals of mathematical education that have been oriented towards the acquisition of concrete contents and primarily procedural knowledge and skills increasingly get complemented with conceptual and process knowledge or in other words to knowledge and skills oriented into finding ways and strategies for solving problems that are also transferable to other school subjects and to areas outside school (Cotič, 2010).

In today's world the relevance of procedural knowledge and skills has diminished, while the need for problem solving knowledge and skills has substantially increased. The increasing significance of complex knowledge and skills gets emphasised, which include everything from fundamental skills of learning, computation to the awareness of complex problems and ways of solving 
Cotič, M., Felda, D., Žakelj, A.: Taxonomy of Learning Objectives at Elementary... Научни скуп „Наука и настава у васпитно-образовном контексту” • стр. 335-346

them. There are changes in the ways of thinking, of what is knowledge, from understanding knowledge as being unambiguous and unchangeable to being complex and dynamic. Theories and classification of knowledge represent the starting point for debate about kinds and aspects of knowledge. It is vital both for elementary school teachers and for mathematics teachers as well as for teachers of the didactics of mathematics to be aware of the different aspects, types, and levels of knowledge, to be able to choose which of them should be given priority in diverse situations, and to knowin what ways to introduce them into the teaching of mathematics, how to discuss them, to consolidate, and finally also how to test and assess them (Cotič, 2010).

\section{TESTING AND ASSESSING KNOWLEDGE IN THE TEACHING OF MATHEMATICS}

The process of learning is extremely complex, as in teaching the teacher must take a series of relevant didactic elements into account such as: motivation, various methods of active learning that should assist learners in constructing knowledge and meaningfully apply them - in accordance with the situation in the classroom, learning matter, learners' prior knowledge - in the learning process as needed. We teachers must therefore be aware of the importance of permanently monitoring or testing the knowledge of learners, which does of course not mean that in monitoring learner's achievements the teacher should only monitor and verify final facts, but mainly also in what ways pupils construct their conceptual imaginings with the purpose to influence the changing of erroneous ideas. Verification of knowledge on the one side encourages learners to thinking and clarifying misunderstandings and uncertainties and on the other side also provides feedback to both the teacher and the learners about the attainment of individual learning objectives. Through the verification of knowledge learners gain insight into their own knowledge, into their strong and their weak points, into the degree of understanding and applicability of their knowledge (Žakelj, 2003).

Besides what has been mentioned above the quality of testing and assessing knowledge is also influenced by the choice of forms of testing knowledge. What we have in mind when speaking about "traditional" verification and assessment of knowledgeare often tests with tasks such as: compute, write the rule, solve the equation, draw the triangle - solving more or less closed problems where the objectives and the ways of solving are usually defined in advance. In this way certain types of knowledge can be neglected or even completely ignored in the teaching already. This is why it is especially important any gaps in knowledge are discovered on time, in the phase of learning already, when testing knowledge. This should provide opportunities for learners to amend or correct erroneous or incomplete concepts. 
Cotič, M., Felda, D., Žakelj, A.: Taxonomy of Learning Objectives at Elementary...

Научни скуп „Наука и настава у васпитно-образовном контексту” • стр. 335-346

At this point the significance of formative monitoring of learners' knowledge, based on the participation of learners in the preparation of learning activities; providing appropriate feedback about learners' work in the classroom; encouraging cooperative learning among pupils; and encouraging pupils to self-evaluation of their work. It is important in this that pupils get informed about the quantity of the acquired knowledge in an appropriate way, and especially about its quality (Hargreaves, 2005; Wiliam, 2013).

Kluger \& DeNisi (1996) had discovered that feedback sometimes lowers the performance of learners, so they paid attention to the "moderators" of the effects of feedback. They found that feedback was the least effective when they focused on the personality of the learner, that it was more efficient when focused on the task and the most efficient when they were focused on details in the task and they contained setting the objectives (Wiliam, 2013).

It is important that we teachers are aware that knowledge testing must continuously be intertwined in the learning process, where care is taken that pupils get feedback on the kind and level of demonstrated knowledge. The performance of learners according to the level of the attained knowledge is described with the assistance of taxonomic scales.

\section{Types of taxonomies}

In educational science several taxonomies of cognitive knowledge (Bloom's, Marzano's, Gagne's) are known. Taxonomy is derived from the basic cognitive mental processes that are arranged in a hierarchic relationship, namely from the lowest - simpler to a higher - more complex process.

All the classifications or taxonomies assume that the structure of taxonomic levels is partly hierarchic, and most importantly individual levels in individual tasks are intertwined and sometimes it is difficult to delineate and define them unequivocally. The purpose of taxonomies or classifications is to a large degree setting objectives. In the educational process the whole should be taught, while in testing and assessing care must be taken that all the taxonomy levels are tested and attained. It is necessary to be aware that sorting tasks into taxonomy levels is influenced by the situation in the class, by what has taken place in it before, by what topics and how have been dealt with the pupils, what problems have already been solved with them, it depends on the population, on previous "input" of knowledge, on learners' experience with individual types of tasks. Defining taxonomy levels is therefore as a rule not unequivocal (Žakelj, 2003).

All taxonomy levels are not equally useful for all subject areas. In the following we are going to present three best known taxonomies of cognitive knowledge, namely Bloom's, Marzano's, and Gagne's taxonomies. 
Cotič, M., Felda, D., Žakelj, A.: Taxonomy of Learning Objectives at Elementary...

Научни скуп „Наука и настава у васпитно-образовном контексту” • стр. 335-346

\section{BLOOM'S TAXONOMY}

\section{Bloom's taxonomy of knowledge}

Bloom's classification is one of the best known taxonomies of learning objectives. Bloom and associates formed a taxonomy of learning objectivest hat covers the cognitive, the affective, and the psychomotordomains. In the cognitive domain the following levels were defined: knowledge, comprehension, application, analysis, synthesis, and evaluation.

The performance of learners according to the level of knowledge is described with the assistance of the six-point taxonomy scale:

\section{- Knowledge}

- Knowledge of the individual, reproductive knowledge, knowledge of isolated information items and facts.

- Knowledge of specific facts: knowledge of definitions, facts, axioms, theorems, relations, and basic characteristics. terminology.

- Knowing terminology: being acquainted with the basic symbols and

- Knowing the ways and methods of dealing with the individual: solving simple routine tasks.

- Knowing classifications and categories: recognising diverse mathematical objects and classification thereof.

\section{- Comprehension}

- Translation: the ability of reading tables, graphs, sketches, drawings and mathematical symbols; translation into other forms and viceversa; understanding the content of an assertion; the ability of summarising with own words.

- Interpretation: explaining and clarifying messages and results; the ability of distinguishing between plausible and contradictory conclusions; understanding textual tasks; editing data, understanding their interrelations.

- Extrapolation: the ability of judging and predicting the framework result; predicting effects and consequences.

\section{- Application}

- The functionality of knowledge, integration with other fields and sciences, application directly in everyday life, getting used to "finding one's ways around" mathematics.

- Application of abstractions on special, concrete examples. 
Cotič, M., Felda, D., Žakelj, A.: Taxonomy of Learning Objectives at Elementary...

Научни скуп „Наука и настава у васпитно-образовном контексту” • стр. 335-346

- Analysis

- Analysis of elements: sorting data by relevance; uncovering blurred data; breaking materials to components; distinguishing facts.

- Analysis of relations: clarifying the basic relations and relationships between the given elements; recognising facts that are relevant to the formulation of the underlying assumption; recognising cause-and-effect relations.

\section{- Synthesis}

- Assembling parts into a whole - taking account of the characteristics of the parts, determining correctness and regularities the parts get arranged in such a way that the detected structure becomes visible.

- Production of a report: developing the processes of expressing thoughts and experiences.

- Production of a plan or the choice of the direction of an operation: developing a working plan, a strategy in solving.

- Production of a system of abstract relationships: formulating hypotheses if these require new facts, detecting mathematical regularities, generalisations.

\section{- Evaluation}

- Assessment whether a given method, message is appropriate for the desired purpose and meeting the given or set criteria. Independent, critical and grounded evaluation of phenomena, theories, solutions.

- Evaluation according to internal criteria: assessment of the materials tasks according to the logically precise formulation and consistency, the ability of judgement whether the given facts exactlymatch the assertions - definitions, theorems, evidence, detecting a logical incorrectness.

- Evaluation according to external criteria: comparing theories, generalising facts, use of independent criteria in selecting the method of work - solving tasks (Žakelj, 2003).

In the revised edition (Anderson et al., 2001) of the taxonomy the order of hierarchical levels was reversed; in the new version the taxonomy levels follow each other from remembering via understanding, to applying, analysing, evaluating and creating (synthesis). The level hierarchically set as the highest is creating; another important change is also the determination of diverse kinds of knowledge at each taxonomy level, namely: knowing the facts, conceptual knowledge, procedural knowledge, and metacognitive knowledge. 
Cotič, M., Felda, D., Žakelj, A.: Taxonomy of Learning Objectives at Elementary...

Научни скуп „Наука и настава у васпитно-образовном контексту” • стр. 335-346

\section{GAGNE'S TAXONOMY \\ Gagne's classification of knowledge}

In Gagne's taxonomy the attainments of learners are distributed to three levels: basic and conceptual knowledge, procedural knowledge, and problem solving knowledge.

According to the level of knowledge the performance of learners is described by the means of a taxonomy scale divided into three parts:

\section{- Basic and conceptual knowledge}

Basic knowledge and skills primarily include the knowledge of concepts and facts and recalling of knowledge. The fundamental elements of basic knowledge are: knowledge of individualities, knowledge of specific facts, knowledge of terminology and the basic symbols, knowing classifications and categories, identifying the concept, identifying the terminology and symbols in a given situation, and interrelations.

Conceptual knowledge is understanding concepts and facts. It includes the formulation of concepts, structuring the concepts, and knowledge of relevant facts. The elements of conceptual knowledge are: recognising the concept, imagining, recognising the terminology and symbols in a given situation, definitions and theorems, interrelations.

The teacher can help the learner in constructing conceptual knowledge by:

- assessing when to include new terms and concepts into the learning process;

- knowing how learners construct their knowledge;

- being aware that the structure of existing knowledge influences the order of learning and teaching (Cotič \& Žakelj, 2004).

In the first part of Gagne's taxonomy scale the emphasis in basic and conceptual knowledge is on knowing and understanding concepts and facts.

\section{- Procedural knowledge}

It consists of knowing and efficiently managing algorithms and procedures. It is divided into routine and complex knowledge.

Routine procedural knowledge includes performing routine procedures, the use of rules and forms, standard computational procedures, solving simple noncompound tasks, tasks with fewer data, etc.

Complex procedural knowledge includes the use of complex procedures, 
Cotič, M., Felda, D., Žakelj, A.: Taxonomy of Learning Objectives at Elementary... Научни скуп „Наука и настава у васпитно-образовном контексту” • стр. 335-346

knowledge and effective managing of algorithms and procedure (methods, processes); the use of rules, laws, procedures, compound tasks with more data (Cotic \& Žakelj, 2004).

In the second part of Gagne's taxonomy scale the emphasis with routine procedural knowledge is on the use of procedures, while with complex procedural knowledge it is on analysis and synthesis thereof.

\section{- Problem solving knowledge}

Nowadays we wish to convey more than just routine knowledge to learners, this is why the desire and demand for learning problem solving knowledge in mathematics classes are increasingly present. Learners must be offered tasks for which they do not know the path of solving, as such tasks verify problem solving knowledge (Cotič \& Žakelj, 2004).

Problem solving knowledge is application of knowledge in new situations, application of combinations of several rules and concepts in being confronted with a new situation, the use of conceptual and procedural knowledge. The basic elements of problem solving knowledge are: setting up of the problem, checking the data, strategies of solving, the use of knowledge or transfer of knowledge, mental skills, and metacognitive competences (Žakelj, 2003).

We are talking about investigating a problem, when:

- the process of solving is taking place independently, with the learner's own idea;

- the learner reaches a new solution, which she or he applies in solving new problems;

- the learner uses the transfer of knowledge, which means he transfers the method of solving into new situations (Cotič \& Žakelj, 2004).

\section{Relations between types of knowledge.}

Types of knowledge are related to one another. We never use just one type of knowledge, e.g. procedural or problem solving knowledge, but one and the other intertwined (Žakelj, 2003). Every teacher's most difficult problem is to find the right mixture when teaching different types of knowledge: knowing, comprehending, procedural, and problem solving knowledge, or, as one of the teachers expressed it: "It is the most difficult to define the right measure between teaching computation and teaching to think." (Cotič, 2010). This is why it is not possible to attribute some types of knowledge greater importance than to others, as they are so intertwined that it is practically impossible to separateone from another easily.

- Conceptual knowledge represents to a certain degree condition for procedural knowledge (a procedure can be performed even if we do not 
Cotič, M., Felda, D., Žakelj, A.: Taxonomy of Learning Objectives at Elementary... Научни скуп „Наука и настава у васпитно-образовном контексту” • стр. 335-346

understand it, but usually we should have at least partial understanding about the object with which we are operating).

- Problem solving knowledge is partly general and partly it is related to concrete contents and it requires solid conceptual and procedural knowledge, even the understanding of procedures.

- Types of knowledge indisputably influence one another: knowing procedures to a certain degree also influences understanding of concepts (Žakelj, 2003)

\section{Contents, objectives, and Gagne's taxonomy scale}

In assessment of knowledge care is taken in different ways that objectives and areas of monitoring are adequately represented, both from the perspective of contents and from the perspective of taxonomy. It is important the type of knowledge is tested and assessed that we in fact want to test or assess. For the selected thematic set we select the objectives of testing, which we meaningfully distribute across Gagne's taxonomy scale. By formulating such a table we ensure that verification or assessment will contain the right proportions of individual contents and objectives that will reflect the desired range of cognitive processes or taxonomy levels (Žakelj, 2003).

Testing and assessment have their specific characteristics and regularities; the implementation thereof requires appropriate conditions and teacher qualifications. Research (Valenčič Zuljan \& Kalin, 2007) has shown that most teachers (nearly three quarters of them) are aware of the importance of operational planning and taxonomic classification of learning objectives for quality assessment, which is also consistent with the didactic aspects of the curricular reform.

In teaching mathematics at elementary level a high degree of correlation between the processes of testing, assessment and monitoring, planning, and dealing with certain items of knowledge. In order for the learned knowledge to be upgraded, also the learner's prior knowledge plays an important role.

\section{MARZANO'S TAXONOMY}

\section{Marzano's classification of knowledge}

Marzano's taxonomy distinguishes between content and lifelong or process knowledge that is further divided into complex thinking, data processing, communication, cooperation in group, and development of mental habits.

In Marzano's classification of knowledge it is about an area of diverse mental processes or complex thinking and thus contribution to an active role of learners and to process-based approach. 
Cotič, M., Felda, D., Žakelj, A.: Taxonomy of Learning Objectives at Elementary... Научни скуп „Наука и настава у васпитно-образовном контексту” • стр. 335-346

Marzano's classification of knowledge also provides assistance to teachers in structuring the learner-centred type of teaching where emphasis is on systematic encouraging of complex thoughts of learners. To the latter the model is of assistance in constructing knowledge and acquiring skills and in developing metacognition (RutarIlc, 2006).

Marzano's taxonomy advocates intertwining of content aspects of knowledge with process aspects, as in the phase of acquiring knowledge mental processes participate in the construction thereof, while in the phase of upgrading and application of knowledge make this possible. Intertwined content and process knowledge is therefore of lifelong nature: lasting, efficient, and useful in the most diverse new situations.

Awareness is important that besides complex thinking also other aspects of knowledge and processing thereof are important, namely the ones listed below:

- Complex thinking: comparison, classification, reasoning with induction and deduction, justifying, abstracting, perspective analysis, decisionmaking, investigation, solving problems, experimental research, analysis of errors, invention.

- Work with sources: gathering, selecting, analysis, interpretation, synthesis, assessment of applicability and value of data; etc.

- Presentation of ideas: clarity of expression, effectiveness of communication with diverse publics and in diverse ways, creation of quality products, etc.

- Cooperation: pursuing common goals, use of interpersonal skills, assuming diverse roles in the community, etc. (RutarIlc, 2006).

In a process designed in this way learners shape mental habits that are valuable aspects or qualities of thinking. Because it is frequently performed, it is built into the individual becoming part of their customary repertoire.

Mental habits develop as a result of the process that requires from learners to be creative, critical, and reflective. Teachers must know and understand individual mental habits and develop them in themselves so that learners could internalise them first by observing the teacher and later with understandingmental habits (RutarIlc, 2006).

In order to ensure the active role of learners and to encourage different mental processes in learners, it is important that the goals set require of students activity and diverse mental processes. This means that the set tasks, questions and activities activate learners by coming to conclusions with their own activity and discovery (RutarIlc, 2002), learnes are more able to grasp, interpret and make critical evaluations (Felda \& Bon Klanjšček, 2017). 
Cotič, M., Felda, D., Žakelj, A.: Taxonomy of Learning Objectives at Elementary...

Научни скуп „Наука и настава у васпитно-образовном контексту” • стр. 335-346

\section{CONCLUSION}

Testing and assessment of knowledge have their specific characteristics and regularities and require adequate conditions and teacher qualifications. Knowledge and use of taxonomy is indispensable for quality testing and assessment of knowledge. Due to the specificity of individual subject areas not all the taxonomies or classifications of cognitive knowledge are equally applicable for all of them. This is why appropriate taxonomies for individual subject areas must be selected by special didacticians, as they are the ones who know and understand the content of each individual subject. E.g. for mathematics Gagne's taxonomy is very appropriate, while for languages the same is true of Marzano's taxonomy. Bloom's taxonomy is organised extremely hierarchically, which in mathematics or in languages cannot be sustained. Taxonomy levels in Gagne's taxonomy are not hierarchical and are interrelated. We also never use just - for example - procedural or problem solving knowledge, but intertwine one and the other type. This is why it is not possible to assign some types of knowledge greater importance than others, as they are so intertwined it is not easy to distinguish between them. We must also be aware that in mathematics the understanding of a concept, term, definition, etc. is often more demanding than the application of a concept in solving problem situations and problems. The significance of diverse types of knowledge often depends on external circumstances, the purpose of schooling, teacher's subjective judgement, etc.

It is true of all of them, however that for quality assessment sound operational planning and taxonomic classification of learning objectives is crucial.

\section{References}

Anderson, L. W., Krathwohl, D. R., Airasian, P. W., Cruikshank, K. A., Mayer, R. E., Pintrich, P. R., Raths, J. \& Wittrock, M. C. (2001). A Taxonomy for Learning, Teaching, and Assessing: A Revision of Bloom's Taxonomy of Educational Objectives. Boston: Allyn \& Bacon.

Cotič, M. (2010). Vrednotenje matematičnega znanja in objektivnost učiteljeve ocene. Didactica Slovenica: časopis za didaktiko in metodiko, 25(1), 39-54.

Cotič, M. \& Žakelj, A. (2004). Gagnejeva taksonomija pri preverjanju in ocenjevanju matematičnega znanja. Sodobna pedagogika, 55(1), 182-192.

Felda, D. \& Bon Klanjšček, M. (2017). Teaching Statistics in the Background of Teaching Mathematics. The New Educational Review, 48(2), 65-75.

Hargreaves, A. (2005). Extending educational change. New York: Springer, cop.

Kmetič, S. (1996). Prispevki k poučevanju matematike. Maribor: Rotis.

Kluger, A. N. \& DeNisi, A. (1996). The Effects of Feedback Interventions on Performance: a Historical Review, a Meta-Analysis, and a Preliminary Feedback Intervention Theory. Psychological Bulletin, 119(2), 254-284. 
Cotič, M., Felda, D., Žakelj, A.: Taxonomy of Learning Objectives at Elementary...

Научни скуп „Наука и настава у васпитно-образовном контексту” • стр. 335-346

RutarIlc, Z. (2006). Didaktična prenova gimnazijali kako pod pretišole pri tem, da bododijake pripravljalena »jutrišnje« probleme. In M. Turk Škraba (ed.): Vpeljevanje sprememb v šole - konceptualni vidiki. Ljubljana: Zavod Republike Slovenije za šolstvo.

RutarIlc, Z. (2002). Aktivni učenec: zakaj in kako?. In A. Zupan (ed.): Modeli poučevanja in učenja. Zbornik prispevkov (10-17). Ljubljana: Zavod RS za šolstvo.

Valenčič Zuljan, M. i Kalin, J. (2007). Učitelj - temeljni dejavnik v procesu inoviranja pedagoške prakse. Sodobna pedagogika, 58(2), 162-179.

Wiliam, D. (2013). Vloga formativnega vrednotenja v učinkovitih učnih okoljih. V S. Sentočnik (ur.), O naravi učenja. Ljubljana: ZRSŠ.

Žakelj, A. (2003). Kako poučevati matematiko. Teoretična zasnova modela in njegova didaktična izpeljava. Ljubljana: Zavod Republike Slovenije za šolstvo.

\section{Мара Цотич}

Универзитет Приморска, Педагошки факултет

Дарјо Фелда

Универзитет Приморска, Педагошки факултет

Амалија Жакељ

Универзитет Приморска, Педагошки факултет

\section{ТАКСОНОМИЈА ЦИЉЕВА УЧЕЊА НА ОСНОВНОМ НИВОУ}

\section{Резиме}

Тражећи одговор на питање шта представља тежиште у подучавању и учењу и стога и у тестирању и оцењивању знања, као и у интерпретацији ученичкоих достигнућа, таксономије циљева учења за когнитивну област могу бити од помоћи. У образовним наукама постоји неколико таксономија когнитивног знања (Блум, Марцано, Гање). Таксономија се изводи из основних когнитивно-менталних процеса који су поређани по хијерархиским односима, наиме од најнижегнајједноставнијег до највишег - најсложенијег процеса.

Рад представља увод у Блумову, Марцанову и Гањеову таксономију. Блумова таксономија је једна од најпознатијих класификација циљева учења, где су Блум и сарадници формирали таксономију когнитивних, конативних и психомоторичких циљева учења. У когнитивној области су дефинисани следећи нивои: памћење, разумевање, примена, анализирање, синтетизовање и процењивање. Гањеова класификација класификује постигнућа ученика у: основно и концептуално знање, процедурално знање и познавање решавања проблема. Марцанова таксономија разликује познавање садржаја и доживотно или знање у процесу, који се даље деле у сложено размишљање, обраду података, комуникацију, сарадњу у оквиру групе и развој менталних навика.

Кључне речи: таксономија, Марцанова таксономија, Блумова таксономија, Гањеова класификација знања, тестирање знања. 